\title{
The impact of CEO overconfidence on real earnings management: Evidence from $M \& A$ transactions
}

\author{
Sawssen Khlifi ${ }^{1, a}$ and Ghazi Zouari ${ }^{\mathrm{a}}$

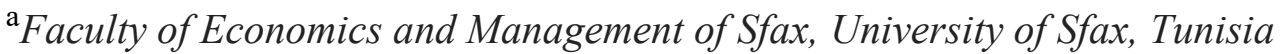

\begin{abstract}
Research Question: Does CEO overconfidence have an effect on the level of real earnings management (REM) in the mergers and acquisitions (M\&A) context?

Motivation: the relationship between the overconfident manager's behavior and REM in the context of M\&A has gained momentum in the accounting and financial studies. In this context, the present work will enrich the literature on behavioral finance and REM in the M\&A context.

Idea: This study was to investigate the effect of overconfidence as part of the manager's cognitive characteristics on the level of REM in M\&A context.

Data: The data were collected from the annual reports of the companies to build an M\&A database and the Thomson Reuters database for the other variables. This study used panel data analysis on a sample of $280 \mathrm{M} \& A$ deals of American listed firms indexed in the S\&P500 between 2012 and 2018. The total sample was divided into two subgroups according to whether the companies are involved in M\&A transactions (test sample) or not (control sample).
\end{abstract}

Tools: To test study's hypotheses, we applied multiple regression analysis based on panel data using the annual reports and Thomson Reuters database.

Findings: The main finding of this study is related to the positive effect of overconfident manager's behavior on REM in the M\&A context. The results show that overconfident managers of acquiring and target companies manage their results upwards using REM.

Contribution: The present study provides a new addition to the prior literature by exploring the contributions of behavioral finance in studying the reality and perspectives of the real earnings management in the presence of an overconfident manager's behavior in the M\&A market.

\footnotetext{
${ }^{1}$ Corresponding author: Sawssen khlifi, Department of Accounting, Faculty of Economics and Management of Sfax, Tunisia, email addresses: sawssen1.klifii@gmail.com
} 
Keywords: CEO overconfidence, Real earnings management (REM), Mergers and Acquisitions (M\&A).

\section{JEL codes: G34, M49}

\section{Introduction}

With the new global economy, global competition in the market is becoming increasingly intense. To remain impregnable in the face of fierce competition, mergers and acquisitions (M\&A) have become an essential means to gain basic competitiveness and increase market share. As a result, M\&A transactions have recently increased significantly in the United States. Indeed, a merger is considered to be a complex legal operation, whereby two or more companies unite into a single one.

Companies use M\&A, which is as an external growth strategy (Cioli et al., 2020; Elrazaz et al., 2021), to improve their financial and accounting position. Thus, it is well established that M\&A transactions are important and popular means of achieving business growth (Dezi et al., 2018). Although the financial literature continues to question whether M\&A transactions improve the wealth of acquiring companies, it is generally accepted that shareholders of target companies receive a premium higher than that of the market after an M\&A transaction is announced. Similarly, this strategy represents the first external mechanism of control of executives having an incentive, disciplinary, and curative role in the US market (Chao et al., 2019).

However, the merged and acquiring company is influenced by the behavior and competence of its manager, who seeks to manage the result achieved. Indeed, the manager may make decisions regarding the accounting and financial choices to influence the accounting result and also the choice of the methods for valuing the company's assets. In this context, there is a general agreement in the literature that the behavior and personal characteristics of the manager influence the accounting choices concerning M\&A transactions, which raises control, governance, and valuation issues. In this context, the analysis of the executive's behavior involves the basic principle of behavioral finance. Hence the need to analyze the impact of the behavioral bias, i.e., "overconfidence"(Libby\& Rennekamp, 2012; Cho et al., 2015; Hribar \& Yang, 2016; Kouaib \& Jarboui, 2016; Sutrisno \& Karmudiandri, 2020; Kuo et al., 2021) to assimilate its impact on the REM level within firms involved in M\&A deals.

For example, an executive's overconfidence, including investment policy, influences the company's decisions (Ben-David et al., 2013; Hu et al., 2013; Hribar \& Yang, 2016; Hwang et al., 2020). Thus, through M\&A, a company implements its 
integration policies, specialization, or diversification to make the most important investment decisions given the strategic nature of these decisions and their long-term impact on the operational and financial restructuring procedures of the company (Bhabra \& Huang, 2013; Elrazaz et al., 2021). Furthermore, managers use M\&A for economic, disciplinary, or opportunistic reasons. As a result, the behavior of the manager is important in the accounting choice and decision-making in M\&A transactions.

The opportunistic behavior of the manager results in the manipulation of the results. Therefore, after the major financial scandals, the manipulation of the result has been the subject of much debate and has attracted growing interest. In this study, we only examined real earnings management (REM). Recently, REM has become the most dominant method in the business world (Graham et al., 2005; Roychowdhury, 2006; Chouaibi et al., 2019; Kuo et al., 2021; Elrazaz et al., 2021). Roychowdhury (2006) distinguished three techniques of manipulating real activities: an abnormal operating cash flow (AB_CFO), abnormal production costs (AB_PROD) and abnormal discretionary expenses (AB_EXP).

Furthermore, the relationship between the overconfident manager's behavior and REM in the context of M\&A has gained momentum in the accounting and financial studies. In this context, our research aimed to explain the impact of an overconfident manager's behavior on REM in the context of US merged and acquiring companies.

To this end, this study was based specifically on the US context, as it is very large and thus allows for a sufficiently large and representative sample and potentially provides more generalizable and robust results. Also, the US economic context provides an interesting framework for research because of the diversity of normative choices and accounting and regulatory methods, as well as the flexibility offered to executives in the choice of accounting practices.

The remainder of the paper is structured as follows: Section 2 presents the literature review and research hypotheses. Section 3 outlines the research design highlighting the description of the sample, the definition of the variables, and the analyses used. Section 4 presents the main empirical findings. Finally, the conclusions and limitations of the research are presented in section 5.

\section{Literature review and hypotheses development}

In recent years, considerable attention has been paid to the personal characteristics of CEOs. It is worth noting that managers can influence the success of M\&A investment projects through their accounting choices in this area. This phenomenon can be described as REM. 
The study of earnings management is part of research in the positive accounting theory, which deals with the accounting choices observed within companies. Thereby, REM is a practice that involves manipulating the cash flow of the company. Therefore, it can relate to the three types of cash flows of a firm, namely cash flows from investment, financing, or even operating activities. Although REM has been defined differently by different authors, the same main idea persists in all these definitions. Our study is part of the work of Roychowdhury (2006) who defines REM as "deviations from normal operational practices, motivated by the desire of managers to mislead at least some stakeholders, in particular making them believe that certain financial reporting objectives have been met in the normal course of operations. These differences do not necessarily contribute to the value of the company even if they allow managers to meet certain reporting objectives". The author presents three types of real activities manipulation: an abnormal operating cash flow (AB_CFO), abnormal production costs (AB_PROD) and abnormal discretionary expenses (AB_EXP).

Our study presents REM in the context of M\&A. Indeed, Academic works on executive accounting practices in M\&A transactions have focused on verifying the existence of REM in the participating firms during the period of the transaction (Farooqi et al., 2020). According to these works, executives of M\&A initiating and target firms would be encouraged to adopt discretionary accounting and financial choices to influence the transaction price, especially when the transaction is equity-financed (Heron \& Lie, 2002; Cioli et al., 2020; Elrazazet al., 2021). Indeed, according to Elrazaz et al. (2021), this situation would encourage managers of acquiring companies to adopt accounting choices that improve the value of their companies just before the transaction to minimize the number of shares to be issued. Indeed, much of the psychological literature and the behavioral theory of M\&A suggest that overconfidence is one of the most important behavioral biases in the M\&A decision-making process. Thus, the behavior of the manager is central in the accounting choice and decision making for M\&A transactions (Hwang et al., 2020). In this context, the present study aimed to study, among other things, the behavior of the overconfident executive in the context of merged companies. Furthermore, previous works have shown that managers insist on the importance of manipulating reported earnings upwards or downwards around several specific corporate events, such as initial public offerings (IPOs), seasoned equity offerings (SEOs), M\&A, etc. As a strategic expansion behavior, M\&A activities are vital for companies (Zhang, 2014).

However, empirical studies on the relationship between overconfident manager's behavior and REM in the M\&A transactions context are limited. Indeed, Hwang et al. (2020) found that a high level of managerial overconfidence is associated with a high level of M\&A activity. Chatterjee and Hambrick (2007) established a relationship between overconfident managers and earnings performance. They pointed out that overconfident executive favor acquisitions because they are very 
confident in their ability to achieve better results than those of target companies. Besides, the abnormally high departure rate of managers of acquired companies during the first two or three years following an acquisition has attracted much attention in the strategy literature (Krug \& Hegarty, 1997; Heron \& Lie, 2002; Custódio \& Metzger, 2013; Hwang et al., 2020).

Several researchers find that investors react differently to executives with different characteristics in M\&A announcements (Huang \& Kisgen, 2013; Custódio \& Metzger, 2013; Nguyen, 2015). This work relates to the literature on managers' overconfidence in corporate finance. Malmendier and Tate (2008) suggest that managers' overconfidence can lead to value-destroying transactions. The number of previous studies on the consequences of biased managers has grown considerably (Malmendier \& Tate, 2005, 2008; Hwang et al., 2020). Indeed, biased managers may manage financing and investment decisions differently (Malmendier \& Tate, 2005), pursue value-destroying acquisitions (Malmendier \& Tate, 2008), and miscalculate future profits (Hribar and Yang, 2011). Moreover, studies by Malmendier and Tate (2008) and Ferris et al. (2013) have examined the extent to which overconfidence can help explain M\&A decisions and the various features of the deal itself. They have shown that overconfident managers are more likely to pursue acquisitions when their companies have abundant internal resources. Similarly, these studies have indicated that overconfident managers are much more likely than other managers to undertake a diversified merger. Finally, they noted that overconfident managers more often use money to finance their mergers. As a result, overconfidence can explain the number of offers made by an executive, the frequency of diversified acquisitions, and the use of cash to finance a merger operation. Although the causes and performance of mergers have been widely examined in the literature, few studies have focused on executive overconfidence as a factor that explains these operations.

Indeed, Roll (1986) was the first to recognize that the influence of individual decision-making by managers could have an impact on the decision whether to engage in merger activity or not. This author argued that executives conduct relatively few mergers during their careers and are therefore unable to learn from their previous mistakes. Moreover, the presence of these cognitive biases encourages managers to put forward their judgment in decision making and to engage in very complex transactions, such as the diversification of acquisitions. Because of their overconfidence, these executives tend to underestimate the risks associated with a merger or overestimate the potential synergy gains from a business combination (Ferris et al., 2013; Hwang et al., 2020).

Likewise, Liu and Zou (2008) showed that overconfident managers are more likely to conduct M\&A transactions than other managers. Furthermore, this study showed that managerial overconfidence has a negative impact on the long-term performance of companies after M\&A transactions. The results obtained suggest that the overconfidence of the target companies' managers also negatively affects the returns 
on company purchase announcements, and this negative impact is particularly strong when the managers of the acquired and target companies are overconfident.

Recent works have identified other important effects of managerial overconfidence in the context of merged companies. Indeed, Malmendier and Tate (2005) find that overconfident managers are more likely to use internal sources of financing for investment projects, and to invest more when internal liquidity is abundant. For his part, Ben-David (2007) reports that companies with overconfident managers engage in more dynamic financing as well as other managerial policies.

To promote the likelihood of successful M\&A transactions and to protect the interests and reputation of companies and individuals, the managers of acquiring companies adopt REM to continuously inflate earnings, with the aim of sending a signal of success to the capital market and enhancing investor confidence. Thus, the behavior deviates from the company's optimal operating decision and directly leads to changes in cash flow.

Also, executives are motivated to manipulate real activities before M\&A to increase the market value of their company. As a result, the manipulation of real activities may affect cash flows and accruals in some cases. Although several studies have shown that managers manipulate real activities to avoid reporting annual losses or particular earnings thresholds, there is little research that examines whether managers attempt to increase the prices of their companies prior to the M\&A through real activities. There is evidence that M\&A payment methods can also affect the manipulations of real activities. For example, Zhu and $\mathrm{Lu}$ (2013) and Farooqi et al. (2020) find that managers are more inclined to manipulate earnings in stock mergers before M\&A.

Furthermore, Malmendier and Tate (2005) argue that overconfident managers are more sensitive to cash flow than their peers. Indeed, when their financial resources are abundant, overconfident managers tend to overestimate the return on their investment projects and over-invest in them. However, when companies are financially constrained, overconfident managers tend to reduce the investment budget and therefore pay less dividends to shareholders than non-confident ones. Since overconfident managers see external financing as the most expensive option, they pay less dividends to create financial margin for future investment needs (Deshmukhet al., 2013). Besides, Malmendier and Tate (2008) and Hwang et al. (2020) provide empirical evidence that overconfident managers are more likely to buy another firm than their non-overconfident colleagues in a single transaction. Similarly, a study by Nguyen (2015) on a sample of 622 mergers of 306 firms in the United States between 2006 and 2013 suggests that overconfident executives are the main participants in M\&A transactions. Based on the above, we find that overconfident managers manage their results upwards by real activities through their commitment to M\&A investments. We, therefore, propose the following hypothesis: 
Hypothesis: managerial overconfidence has a positive effect on real earnings management in mergers and acquiring.

\section{Research design}

\subsection{Sample selection}

Our sample en compassed publicly available data from companies whose acquirer is listed on the S\&P500 Index in the USA during the 2012-2018 period (Table 1). This period was chosen because it is characterized by a remarkable evolution of M\&A transactions in the US context. Two sources of information were used to collect the data: the annual reports of the companies to build an M\&A database and the Thomson Reuters DataStream for the other variables. The search criteria used to get the data are as follows:

- Index: S\&P 500

- The target company must be a US company listed on a US market (NYSE, $\mathrm{N}^{2}$ ASDAQ),

- Time: the transaction must be closed in the period between 01/01/2012 and $31 / 12 / 2018$.

- The value(equity + net financial debt) of the transaction must be at least $\$ 1$ billion.

- For a firm to be considered a merger, the new owner must possess the majority of the merged company's assets (i.e., more than $50 \%$ of the assets).

- The merger operation must be completed only between US companies.

- The acquisition operation must be completed only between US companies.

Our sampling process was used to subdivide the total sample into a test sample (merged and acquiring firms) and a control sample (non-merged firms). By calculating the median of our sample, we were able to rank each of the two groups:

G1: firms involved in M\&A transactions

G2: firms not involved in M\&A transactions

Table 1. sample selection

\begin{tabular}{lcc}
\hline Panel A: Construction of the final sample & & \\
\hline Sample & $\#$ firms & $\#$ Obs. \\
initial Sample: S\&P 500 index & 500 & 3,500 \\
- firms eliminated (missing data) & $(220)$ & $(1540)$ \\
Final Sample & $\mathbf{2 8 0}$ & $\mathbf{1 9 6 0}$ \\
Panel B: Distribution of the sample as a function of M\&A & & \\
Firms & $\#$ Obs. & $\# \%$ \\
Test Sample (202 merged and acquiring firms) & 1414 & $79.28 \%$ \\
Control Sample(78non-merged firms) & 546 & $20.72 \%$ \\
Total & $\mathbf{1 9 6 0}$ & $\mathbf{1 0 0} \%$ \\
\hline
\end{tabular}


The impact of CEO overconfidence on real earnings management:

Evidence from M\&A transactions

Table 2 provides some details of the sector in which the acquirer operates, using American SIC codes. The Manufacturing and Services sectors are well represented in the sample, while no acquiring company operates in the Construction, Finance, Insurance, Real Estate, and Public Administration sectors.

Table 2. Sectors acquiring companies / sample Composition by industry

\begin{tabular}{lccc}
\hline \multicolumn{1}{c}{ American SIC Code - Sector } & Test sample & $\begin{array}{c}\text { Control } \\
\text { sample }\end{array}$ & $\begin{array}{c}\text { Total } \\
\text { sample }\end{array}$ \\
\hline 0100-0900: Agriculture, Forestry, & 11 & 5 & 16 \\
Fishing & 23 & 12 & 35 \\
1000-1499: Mining & 0 & 0 & 0 \\
1500-1799: Construction & 74 & 21 & 95 \\
2000-3999: Manufacturing & 14 & 8 & 22 \\
4000-4999: Transportation \& Public & 15 & 3 & 18 \\
Utilities & 29 & 10 & 39 \\
5000-5199: Wholesale Trade & 0 & 0 & 0 \\
5200-5999: Retail Trade & 36 & 19 & 55 \\
6000-6799: Finance, Insurance, Real & 0 & 0 & 0 \\
Estate & $\mathbf{2 0 2}$ & $\mathbf{7 8}$ & $\mathbf{2 8 0}$ \\
7000-8999: Services & & & \\
9100-9999: Public Administration & & & \\
Total & & &
\end{tabular}

\subsection{Variables measurements}

\subsubsection{Real Earnings Management index (REMI)}

For this research, we relied on Roychowdhury's (2006) model, which is often used by other researchers and has proven to be valid (Cohen et al., 2008; Cohen \& Zarowin, 2010; Zang, 2012; Chouaibi et al., 2019; Elrazaz et al., 2020; Kuo et al., 2021). Roychowdhury (2006) mentioned three ways of measuring real earnings management using models developed by Dechow et al. (1998): Abnormal Operating Cash Flow (Abn_CFO), Abnormal Discretionary Expenditure (Abn_DISEXP), and Abnormal Production Cost (Abn_PROD) were calculated. The abnormal levels (the proxy of real earnings management) are determined by subtracting the normal levels of the variables from the real levels of the variables. This means that the error term reflects the abnormal level. The models given below calculate the normal levels of the variables.

First, Roychowdhury (2006) expresses Operating Cash-flows by model (M1):

$$
\frac{\mathrm{CFOt}}{\text { TAt }-1}=\alpha 0+\alpha 1\left(\frac{1}{\text { TAt }-1}\right)+\beta 1\left(\frac{\mathrm{St}}{\text { TAt }-1}\right)+\beta 2\left(\frac{\Delta \mathrm{St}}{\text { TAt }-1}\right)+\varepsilon \mathrm{t}
$$


where

$\mathrm{CFOt}=$ Cash Flow from Operations in period $\mathrm{t}$

TAt- $1=$ Total Assets at $\mathrm{t}-1$

$\mathrm{St}=$ Sales during period $\mathrm{t}$

$\Delta \mathrm{St}=$ Change in sales between $\mathrm{t}$ and $\mathrm{t}-1$

$\varepsilon t=$ Residual of the regression at time $\mathrm{t}$

Roychowdhury (2006) states another way to manage earnings that consist of reducing discretionary expenses, which are the sum of advertising, R\&D and selling, as well as general and administrative expenditures. Advertising expenses were omitted since the Thomson Reuters database did not contain data on this variable. Model (M2) for discretionary expenditures is written as follows:

$$
\frac{\text { DISEXPt }}{\text { TAt }-1}=\alpha 0+\alpha 1\left(\frac{1}{\text { TAt }-1}\right)+\beta\left(\frac{\text { St }-1}{\text { TAt }-1}\right)+\varepsilon t
$$

where

DISEXPt $=$ Discretionary expenses in period $t$

St- $1=$ Sales at $\mathrm{t}-1$

Finally, Roychowdhury (2006) uses the variable production costs, i.e., the sum of costs of goods sold and the change in inventory, in model (M3):

$$
\frac{\text { PRODt }}{\text { TAt }-1}=\alpha 0+\alpha 1\left(\frac{1}{\text { TAt }-1}\right)+\beta 1\left(\frac{\text { St }}{\text { TAt- } 1}\right)+\beta 2\left(\frac{\Delta \text { St }}{\text { TAt }-1}\right)+\beta 3\left(\frac{\Delta \text { St }-1}{\text { TAt }-1}\right)+\varepsilon t
$$

where

PRODt $=$ Production costs in period $\mathrm{t}$

$\Delta \mathrm{St}-1=$ Change in sales between $\mathrm{t}-1$ and $\mathrm{t}-2$

Subsequently, the three proxies were cumulated to see the overall impact of REM, which was reflected in the REM_proxy variable. The residuals of operating cash flow and the abnormal level of discretionary expenses were multiplied by $(-1)$ because higher values indicate higher levels of these proxies reduced by the firms to manage earnings. Thus, by multiplying these proxies by -1 , the interpretation of the real earnings management is simpler.

In this sense, the REM index is equal to the sum of the residuals of the 3 models as a proxy of the dependent variable while multiplying M1 and M2 by -1 .

$$
\text { REMI }=(-1) * \mathrm{AbnCFO}+(-1) * \mathrm{AbnDISEXP}+\mathrm{AbnPROD}
$$




\subsubsection{CEO overconfidence proxy (CEOOVC)}

The great difficulty in accounting studies dealing with the behavioral approach of the overconfident executive is the identification of a relevant and operational measure of overconfidence of managers. Following Schrand and Zechman (2012), we adopted a measure that is available in the Thomson Reuters Datastream. This measure has been adopted by several researchers, such as Schrand and Zechman (2012), Gayoung and Jong (2015), Kouaib and Jarboui (2016) and Sutrisno and Karmudiandri (2020). We define the executive's overconfidence variable as a proxy of five items, namely industry-adjusted net dollars of acquisitions made by the firm, industry-adjusted debt to equity ratio, convertible debt or preferred stock, dividend yield, and industry-adjusted excess investment. This measure takes 1 if the sum of the five items below is equal to or greater than 3 and 0 otherwise. Industry-adjusted net acquisition (ACQUIRE_INDADJ) is equal to 1 if the net acquisitions on the cash flow statement are in the top quartile of companies in the industry and 0 otherwise. The second component is the firm's industry-adjusted debt-to-equity ratio (DERATIO_INDADJ).The debt ratio equals 1 if the debt/equity ratio is in the top quartile of companies and 0 otherwise. Overconfident CEOs will choose risky debt and find evidence that overconfident managers have a longer debt duration as a measure of risky debt. Thus, the third component is Risky debt (RISKYDT). This component is equal to 1 if the debt convertible into preferred shares is greater than zero and 0 otherwise. The fourth component is the dividend yield (DIVYLD), which is equal to 1 if the dividend yield is zero and 0 otherwise. The fifth component is industry-adjusted excess investment and is coded XSINVEST_INDADJ. Although investment is affected by financial reporting policies and firms make investments primarily for growth and potential profit, the reliability literature suggests that managerial overconfidence is associated with investment decisions (Malmendier \& Tate, 2005, 2008; Ben-David et al., 2013; Ahmed \& Duellman, 2013; Pikulina et al., 2017). In this context, two relevant works by Schrand and Zechman (2012) and Ahmed and Duellman (2013) have revealed that the level of investment is higher for companies led by managers who have overvalued these projects and, therefore, overinvestment is a potential consequence of overconfidence.

With

$$
\text { Invest }_{i t}=\beta_{0}+\frac{{\text { Asset growth } \text { rate }_{i t}}_{\text {Sales growth rate }}}{\text { St }}+\varepsilon_{i t}
$$

Invest: the total investment is defined as the net increase of tangible and intangible fixed assets by the total assets.

Asset growth rate: the changes in the assets of company $i$ from $t-1$ to $t$.

Sales growth rate: the changes in sales of company $i$ from $t-1$ to $t$.

$\varepsilon$ : regression residuals at the end of the financial period for company i.

The error term of the investment model represents the inefficiency of investments, i.e., either over-investment or under-investment. A positive residual means that the 
company makes investments at a higher rate than expected based on sales growth so that over-investment occurs. However, a negative residual implies that actual investment is lower than planned, representing underinvestment. We consider excess investment to be 1 if the residual of its regression is greater than zero and 0 otherwise. The indicator variable CEOOVC takes 1 if no less than three of its five components show that the firm has overconfident manager and 0 otherwise. The five situations designate overconfidence: ACQUIRE_INDADJ is greater than zero, DERATIO_INDADJ is greater than zero, RISKYDT is equal to one, DIVYLD is equal to one, and XSINVEST_INDADJ is greater than zero.

\subsubsection{Control variables}

Several control variables related to REM have been recognized in previous research. The control variables retained in this work were: Firm size (SIZE), which is the natural logarithm of total assets, leverage (LEV) measured as total debt divided by total equity and return on assets (ROA) to control for a firm's profitability. Tobin Q is measured by the ratio of the market value of shareholders' equity and the book value of liabilities to the book value of assets. The merger and acquisition (M\&A) variable takes 1 if the company is involved in M\&A transactions and 0 otherwise.

\subsection{Regression model}

The present work aimed to recognize the effect of the CEO's overconfidence on the level of REM in M\&A context. To this end, we run a multiple regression as follows:

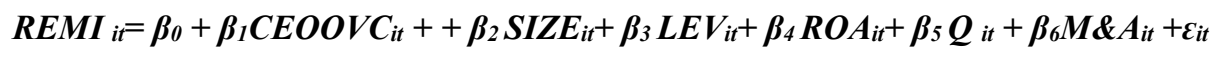

With:

- $\mathrm{REMI}_{\mathrm{it}}$ : Real earnings management index

- $\mathrm{CEOOVC}_{\mathrm{it}}$ : CEO overconfidence index.

- SIZE ${ }_{i t}$ firm size is defined as the natural logarithm of total assets.

- $\mathrm{LEV}_{\mathrm{it}}$ : leverage ratio is measured as total debt divided by total equity.

- $\mathrm{ROA}_{\text {it: }}$ return on assets is measured as net income divided by total assets.

- Q: tobinQ is measured by the ratio of the market value of shareholders' equity and the book value of liabilities to the book value of assets.

- M\&A: merger and acquisition variabletakes1 if a company is merged and acquiring and 0 otherwise.

- $\beta 0, \beta 1, \beta 2, \beta 3, \beta 4, \beta 5$ : the parameters to be estimated

- $\varepsilon_{\text {it: }}$ the random error of firm $\mathrm{i}$ in year $\mathrm{t}$. 


\section{Empirical results}

\subsection{Descriptive statistics}

Table 3 shows the summary of the statistics regarding the dependent, independent, and control variables of the three samples of our work: total, test, and control samples. Panel A reports that the mean value of REMI for the total sample is $1.4 \%$ with a minimum of $-89.2 \%$ and a maximum of $86.7 \%$, which means that REM practices have progressed very significantly for US companies in the S\&P 500 Index over the last few years. For the test sample, the mean value of the REMI is $1.8 \%$ but for the control sample is $1.1 \%$, it thus appears that merged and acquiring companies are more engaged in REM practices than non-merged ones. Panel B presents a summary of the statistics of the CEOOVC and the M\&A transactions variable. By examining the descriptive statistics on the CEOOVC variable, we note that $98.16 \%$ of merged and acquiring companies' managers are overconfident, while $1.84 \%$ are not. Nonetheless, $14.47 \%$ of managers of non-merged and acquiring companies are overconfident compared to $85.53 \%$ who are not overconfident. This finding allows us to conclude that the participation of companies in M\&A transactions is linked to the manager's overconfidence. Regarding the M\&A transactions variable, we find that $73.06 \%$ of the American companies in the S\&P 500 Index are involved in M\&A transactions, while $26.94 \%$ are not involved in M\&A transactions during the study period.

Table 3. Summary statistics of the sample

\begin{tabular}{ccccc}
\hline Panel A: Summary statistics for continuous variables & & \\
\hline \multirow{2}{*}{ Variables } & Statistics & Full sample & $\begin{array}{c}\text { Test } \\
\text { sample }\end{array}$ & Control sample \\
& Mean & 0.014 & 0.018 & 0.011 \\
\multirow{2}{*}{ REMI } & Std. deviation & 0.193 & 0.163 & 0.210 \\
& Minimum & -0.892 & -0.652 & -0.892 \\
& Maximum & 0.867 & 0.657 & 0.867 \\
& Mean & 16.648 & 16.922 & 16.48 \\
SIZE & Std. deviation & 1.394 & 1.403 & 1.359 \\
& Minimum & 12.7037 & 13.732 & 12.703 \\
& Maximum & 21.668 & 20.653 & 21.668 \\
\multirow{2}{*}{ LEV } & Mean & 0.275 & 0.276 & 0.274 \\
& Std. deviation & 0.185 & 0.181 & 0.187 \\
& Minimum & 0 & 0 & 0 \\
& Maximum & 1.940 & 1.940 & 1.192 \\
ROA & Mean & 0.074 & 0.083 & 0.068 \\
& Std. deviation & 0.071 & 0.074 & 0.069 \\
& Minimum & -0.613 & -0.352 & -0.613 \\
& Maximum & 0.485 & 0.485 & 0.325 \\
\hline
\end{tabular}

Vol. 20, No. 3 


\begin{tabular}{|c|c|c|c|c|c|}
\hline \multicolumn{6}{|c|}{ Panel A: Summary statistics for continuous variables } \\
\hline \multirow[t]{2}{*}{ Variables } & Statistics & Full sample & $\begin{array}{c}\text { Test } \\
\text { sample }\end{array}$ & \multicolumn{2}{|c|}{ Control sample } \\
\hline & Mean & 1.139 & 1.149 & \multicolumn{2}{|c|}{1.113} \\
\hline & Std. deviation & 0.818 & 0.816 & \multicolumn{2}{|c|}{0.825} \\
\hline \multirow[t]{2}{*}{$\mathbf{Q}$} & Minimum & -0.891 & -0.755 & \multicolumn{2}{|c|}{-0.891} \\
\hline & Maximum & 6.574 & 6.574 & \multicolumn{2}{|c|}{6.273} \\
\hline \multicolumn{6}{|c|}{ Panel B: Summary statistics for dichotomous variables } \\
\hline \multirow[t]{2}{*}{ Variables } & Sample & Freq $(0)$ & $\%$ & Freq (1) & $\%$ \\
\hline & Full sample & 493 & 25.15 & 467 & 74.85 \\
\hline \multirow[t]{3}{*}{ CEOOVC } & Test sample & 26 & 1.84 & 1388 & 98.16 \\
\hline & Control sample & 467 & 85.53 & 79 & 14.74 \\
\hline & Full sample & 528 & 26.94 & 1432 & 73.06 \\
\hline \multirow[t]{2}{*}{ M\&A } & Test sample & 48 & 3.39 & 1366 & 96.61 \\
\hline & Control sample & 539 & 98.72 & 7 & 01.28 \\
\hline \multicolumn{6}{|c|}{$\begin{array}{l}\text { Notes: Real earnings management index (REMI), CEO overconfidence (CEOOVC), firm's } \\
\text { size (SIZE), leverage ratio (LEV), return on assets (ROA), tobin Q (Q), and merger and } \\
\text { acquisition (M\&A) }\end{array}$} \\
\hline
\end{tabular}

\subsection{Bivariate analysis}

To test our hypotheses, we used the difference between means test on the two groups considered in our study. The M\&A variable is dichotomous because the firms involved in M\&A transactions take 1 (Test sample) while those not involved in M\&A transactions take 0 (Control sample). Then we calculated the REMI for the two groups and checked whether there is a significant difference between their means. Therefore, the hypothesis (H0) to be tested is the absence of a significant difference in the means of the REMI between the two samples.

Table 4. Variables' difference between means

\begin{tabular}{cccc}
\hline $\begin{array}{c}\text { Panel A: The explanatory variables' difference between means with respect to the } \\
\text { existence of M\&A }\end{array}$ & $\begin{array}{c}\text { No. of observations } \\
\text { (firms-years) }\end{array}$ & Means \\
\hline Variables & Level of M\&A firms & 1414 & 0.485 \\
REMI & M\&A 1 & 546 & 0.534 \\
& Non M\&A 0 & 1414 & 0.932 \\
CEOOVC & M\&A 1 & 546 & 0.458 \\
SIZE & Non M\&A 0 & 1414 & 0.122 \\
& M\&A 1 & 546 & 0.076 \\
LEV & Non M\&A 0 & 1414 & 0.528 \\
\hline
\end{tabular}


The impact of CEO overconfidence on real earnings management:

Evidence from M\&A transactions

\begin{tabular}{|c|c|c|c|c|}
\hline \multicolumn{5}{|c|}{$\begin{array}{l}\text { Panel A: The explanatory variables' difference between means with respect to the } \\
\text { existence of M\&A }\end{array}$} \\
\hline Variables & Level of M\&A firms & \multicolumn{2}{|c|}{$\begin{array}{l}\text { No. of observations } \\
\text { (firms-years) }\end{array}$} & Means \\
\hline \multirow{3}{*}{ ROA } & Non M\&A 0 & \multicolumn{2}{|c|}{546} & 0.458 \\
\hline & M\&A 1 & \multicolumn{2}{|c|}{1414} & 0.747 \\
\hline & Non M\&A 0 & \multicolumn{2}{|c|}{546} & 0.744 \\
\hline \multirow[b]{2}{*}{$\mathbf{Q}$} & M\&A 1 & \multicolumn{2}{|c|}{1414} & 16.634 \\
\hline & Non M\&A 0 & \multicolumn{2}{|c|}{546} & 16.732 \\
\hline \multicolumn{5}{|c|}{$\begin{array}{l}\text { Panel B: } t \text { test on explanatory variables and variable to explain as a function } \\
\text { of M\&A }\end{array}$} \\
\hline \multirow[t]{2}{*}{ Variables } & \multirow[t]{2}{*}{ M\&A Hypothesis } & \multicolumn{3}{|c|}{ T-test for equality of means } \\
\hline & & $\mathbf{T}$ & Significance & $\begin{array}{c}\text { Difference } \\
\text { between } \\
\text { means }\end{array}$ \\
\hline REMI & $\begin{array}{c}\text { The unequal-variance } \\
\text { assumption }\end{array}$ & -4.006 & 0.000 & -0.048 \\
\hline CEOOVC & $\begin{array}{l}\text { The unequal-variance } \\
\text { assumption }\end{array}$ & -7.452 & 0.000 & -0.541 \\
\hline SIZE & $\begin{array}{c}\text { The unequal-variance } \\
\text { assumption }\end{array}$ & -2.886 & 0.002 & -0.046 \\
\hline LEV & $\begin{array}{l}\text { The unequal-variance } \\
\text { assumption }\end{array}$ & -2.91 & 0.002 & -0.069 \\
\hline ROA & $\begin{array}{c}\text { The unequal-variance } \\
\text { assumption }\end{array}$ & -0.107 & 0.457 & -0.003 \\
\hline $\mathbf{Q}$ & $\begin{array}{c}\text { The unequal-variance } \\
\text { assumption }\end{array}$ & 0.512 & 0.694 & 0.098 \\
\hline
\end{tabular}

Notes: Real earnings management index (REMI), CEO overconfidence (CEOOVC), firm's size (SIZE), leverage ratio (LEV), return on assets $(\mathrm{ROA})$, tobin $\mathrm{Q}(\mathrm{Q})$, and merger and acquisition (M\&A)

The analysis of the different variables in our model shows the following results. As can be seen in the table 4, there is a significant difference in the REMI between the two groups of companies (merged and acquiring and non-merged) at the $1 \%$ threshold. Besides, the merged and acquiring firms practice less manipulation of real activities as the average REMI of these firms $(0.485)$ is lower than that of nonmerged ones (0.534).

For the behavioral bias of managerial overconfidence, the results show a significant difference between the two groups of companies. Indeed, the average of merged and acquiring firms (0.932) is higher than that of non-merged ones $(0.458)$. Thus, the overconfident managers of merged and acquiring firms are more involved in REM practices than those of the non-merged ones. Similarly, this difference in means is 
significant when observing the difference between means test for unequal variance assumptions or when the results show that the $t$ student $=-7.452$ with a $p$-value of 0.000 .

Regarding the control variables, the results show that there is no significant difference in company size between the two groups. Indeed, the difference between means tests for unequal variance hypotheses reveal a $t$ student of 0.512 with significance thresholds above $10 \%$, implying that this variable is not a determining factor for the merged and acquiring firms. Concerning the debt variable, the results show that there is a significant difference between the two groups of companies. The average indebtedness of firms involved in M\&A (0.282) is higher than that of noninvolved ones (0.258). Similarly, this difference in means is significant, as it has a student equal to $-2,661$, which is significant at the $1 \%$ threshold. Also, the ROA shows a significant difference between the two groups of companies. Merged and acquiring companies (0.077) are more profitable than non-merged ones (0.065). An observation of the difference between means test for unequal variance assumptions shows that the t-student of -1.928 is significant at the $5 \%$ threshold. Finally, there is a significant difference between the two groups of companies in terms of the Tobin $\mathrm{Q}$ variable, which shows the importance of stock market performance in the M\&A market. The average $\mathrm{Q}$ of firms involved in M\&A (0.040) is higher than that of noninvolved ones (0.035) (Table 4). Furthermore, the difference between means test for unequal variance assumptions has at student $=-1.248$ is significant at the $10 \%$ threshold.

\subsection{Multivariate analysis}

We estimated our models (full, test, and control samples) using the multiple regression analysis. Several tests, namely correlation test, homogeneity test, Hausman test, and heteroskedasticity test, were conducted. We estimate the models using STATA 13 software to analyze the results obtained.

We performed a correlation analysis between the explanatory variables using the Pearson correlation matrix. Table 5 shows that all the coefficients are less than 0.7 , which is the benchmark determined by Kervin (1992) and Anderson et al. (2014). This finding demonstrates that there is no problem of multicollinearity. Besides, to better explain the issue, the variance inflation factors (VIFs) were used. As can be seen in Table 5, the VIF values corresponding to all the independent variables range between 1.20 and 1.03, i.e., less than 10. Accordingly, there exists no degradation by the presence of multicollinearity 
The impact of CEO overconfidence on real earnings management:

Evidence from M\&A transactions

Table 5. Pearson correlations for Independent and Control Variables

\begin{tabular}{clllllll}
\hline \multicolumn{1}{c}{ CEOOVC } & M\&A & SIZE & LEV & ROA & Q & VIF \\
\hline CEOOVC & 1 & & & & & & 1.03 \\
M\&A & 0.547 & 1 & & & & & 1.20 \\
SIZE & -0.013 & -0.015 & 1 & & & & 1.04 \\
LEV & 0.046 & 0.057 & -0.127 & 1 & & & 1.11 \\
ROA & 0.018 & 0.016 & 0.008 & -0.051 & 1 & & 1.05 \\
Q & 0.056 & 0.045 & -0.230 & -0.063 & 0.025 & 1 & 1.03 \\
\hline
\end{tabular}

Notes: CEO overconfidence (CEOOVC), merger and acquisition (M\&A), firm's size (SIZE), leverage ratio (LEV), return onassets (ROA), and Tobin $Q(\mathrm{Q})$.

All correlations between variables are significantly smaller than 0.7 (threshold at which serious problems of multi-collinearity begin, Kervin, 1992). In the Pearson test (T-statistics are reported in parentheses) and the index of conditioning,we found that these variables are distinct from each other and are not significant (correlation thresholds above $10 \%$ and thepackaging is less than 1000).

To obtain robust estimates, some tests needed to be conducted. To test the presence of individual effects, we conducted an "F-statistic", which gave a substantial Chisquare value. This finding indicates the existence of individual effects, affirming the heterogeneous nature of the samples (total, test, and control). Afterward, the Hausman test provided a chi-square value equal to 25.42 and a $p$-value $=0.000$ (total sample, Table 6). This result suggests the presence of a fixed-effect model; thus, we implemented the ordinary least squares (OLS) for the fixed-effects model while declining the generalized least squares (GLS) required by the random-effects model. Finally, a heteroskedasticity test at the panel level had to be conducted by applying the Breusch-Pagan test (Table 6). The result of this test was a significant chi-square and, thus, the null hypothesis of constant variance was rejected, which indicates the existence of a heteroskedasticity problem. Accordingly, we used the Eicker-White method with the "robust" option to rectify the standard deviations. Indeed, it is recommended to use standard errors that are robust to heteroskedasticity in testing the hypotheses to make test results more credible.

To study the effect of the overconfident manager on REM in M\&A transactions, we estimated our model using a sample of US companies. The estimation of our fixedeffects model shows that the $\mathrm{R} 2$ within is of the order of 0.043 . This result proves that the explanatory variables contribute to the explanation of the dependent variable at a rate of $4.3 \%$. Therefore, our model has low explanatory power.

Table 6: Regression Results

\begin{tabular}{cccc}
\hline \multicolumn{1}{c}{ Variables } & Full sample & Test sample & Control sample \\
\hline Constant & $-0.349^{* * *}$ & $-0.423^{* * *}$ & -0.228 \\
& $(-3.78)$ & $(-3.97)$ & $(-1.23)$ \\
CEOOVC & 0.010 & $0.021^{* *}$ & -0.041 \\
& $(0.6)$ & $(2.29)$ & $(-1.36)$ \\
\hline
\end{tabular}




\begin{tabular}{lccc}
\hline \multicolumn{1}{c}{ Variables } & Full sample & Test sample & Control sample \\
\hline SIZE & $0.024^{* * *}$ & $0.026^{* * *}$ & $0.020^{*}$ \\
& $(4.38)$ & $(4.15)$ & $(1.88)$ \\
LEV & $-0.066^{* * *}$ & $-0.035^{*}$ & $-0.179^{* * *}$ \\
& $(-3.27)$ & $(-1.66)$ & $(-3.47)$ \\
ROA & $0.209^{* * *}$ & $0.213^{* * *}$ & 0.154 \\
& $(5.80)$ & $(4.93)$ & $(2.25)$ \\
Q & -0.003 & $-0.056^{* * *}$ & -0.024 \\
& $(-0.91)$ & $(-2.94)$ & $(-1.10)$ \\
M\&A & $-0.025^{*}$ & - & - \\
& $(-1.86)$ & & Yes \\
Firm fixed effects & Yes & Yes & Yes \\
Year fixed effect & Yes & Yes & $7.1 \%$ \\
Adj R-squared (\%) & $4.3 \%$ & $4.2 \%$ & 546 \\
Nb. Of Obs. & 1960 & 1414 & $38.34^{* * *}$ \\
Fisher test & $45.11^{* * *}$ & $47.77^{* * * *}$ & \\
Normality test & & & $0.000^{* * *}$ \\
Prob(Skewness) & $0.000^{* * *}$ & $0.000^{* * *}$ & $0.000^{* * *}$ \\
Prob(Kurtosis) & $0.000^{* * *}$ & $0.000^{* * *}$ & $38.34^{* * *}$ \\
Homogeneity test & $45.11^{* * *}$ & $47.77^{* * *}$ & $19.31^{* * *}$ \\
Hausman test & $26.20^{* * *}$ & $20.23^{* * *}$ & \\
Breusch-Pagan test & $32.41^{* * *}$ & $11.47^{* * *}$ & $28.34^{* * *}$ \\
forHeteroskedasticity & & & \\
\hline
\end{tabular}

Notes: REMI: real earnings management index, CEOOVC: CEO overconfidence, SIZE: firm's size, LEV: leverage ratio, ROA: return on assets, Q: tobin Q, and M\&A: merger and acquisition.*, **, and ***indicate significance at the $0.10,0.05$, and 0.01 levels, respectively

Our hypothesis predicts the existence of a positive impact of overconfident manager's behavior on REM in the M\&A context. So, overconfident CEOs of American firms manage earnings upward using REM. We estimated this relationship based on the three sub-samples of this work. The results show a positive sign ( $\beta=0.021$ ) significant at the $5 \%$ level for the test sample. This finding indicates that overconfident managers of merged and acquiring companies are managing their bottom line upwards using REM. Concerning the control sample, the results showed that the coefficient is negative $(\beta=-0.041)$ but not significant. For the full sample, the statistical evidence indicates that the coefficient is positive $(\beta=0.010)$ but not significant. Based on what has been advanced, we can conclude that the test sample has statistical relevance for our research hypothesis. Therefore, our hypothesis that overconfident managers are committed to increasing profits using REM in merged and acquiring companies is strongly supported. These results provide strong evidence that this managerial behavioral bias has a strong influence on the decision making of merged companies and that overconfident managers are much more likely 
to undertake a diversified merger. This could be due to the signals overconfident leaders want to send to the market. They could send a positive message to cover their operational decision making to overestimate future returns on M\&A investments. Therefore, our hypothesis is validated. Finally, regarding the control variables, we note that firm size is the most explanatory variable for REM practices. Indeed, this variable has a positive $(\beta=0.026)$ and significant impact at the $1 \%$ threshold for the test sample. Furthermore, the results showed a positive $(\beta=0.020)$ and significant impact at the $10 \%$ threshold for the control sample. Similarly, the total sample has a coefficient that is positive $(\beta=0.024)$ and significant at the $1 \%$ level. Based on what has been advanced, we can conclude that the larger the size of the companies involved in M\&A transactions, the higher the REM level.

The results of the model estimation regarding the debt variable reveal a coefficient that is negative $(\beta=-0.035)$ and significant at the $10 \%$ threshold for the test sample. The coefficients for the total and the control samples are negative $(\beta=-0.066$ and $\beta=$ -0.179 , respectively) and significant at the $1 \%$ threshold. Thus, this variable is a determining factor for merged and non-merged companies, indicating that the more companies resort to external financing, the more they manage their results upwards. This finding is consistent with the agency theory, which predicts that the higher the debt levels, the higher the level of earnings management.

The ROA variable, which is the most explanatory of the REM practice in merged and acquiring companies, is associated with a positive sign $(\beta=0.213)$ significant at the $1 \%$ threshold for the test sample. Nevertheless, it is positive $(\beta=0.154)$ but is non-significant for the control sample. However, the coefficient is positive ( $\beta=$ 0.209 ) and significant at the $1 \%$ threshold or the total sample. These findings suggest that companies engage in M\&A transactions to increase their return on assets, thereby creating an environment conducive to real activities manipulation practices.

As for the Tobin $Q$ variable, the coefficients are different for the 3 sub-samples. As a result, the estimation of the empirical model gives a negative sign $(\beta=-0.056)$ significant at the $1 \%$ threshold within the test sample compared to a negative $(\beta=-0.024)$ but non-significant sign for the control sample. Thus, these results are similar to those of the total sample, where the coefficient is negative $(\beta=-0.003)$ but non-significant. This shows that merged companies with a Tobin $\mathrm{Q}$ are less incited to manage their results and, therefore, avoid manipulating real activities. This result highlights the importance of this variable in determining REM in merged and acquiring firms.

Concerning the last variable related to M\&A, statistical evidence from the total sample indicates that the coefficient is negative $(\beta=-0.025)$ and significant at the $10 \%$ threshold. This leads us to deduce that under market pressure and strict regulations, the managers of the merged and acquiring companies opt for a more concealed REM to increase the reported results, to protect the company's reputation 
and their personal reputation, and to ensure the proper functioning of the company's future activities by transmitting M\&A signals to the financial market. This less easily detectable behavior may provide more space for manipulation for managers (Cang et al., 2011; Zhang, 2014).

\section{Conclusion}

The purpose of this paper was to examine the effect of managerial overconfidence on the REM in M\&A market. This research work presents several theoretical and practical contributions. Theoretically, we tried to broaden the REM concept in firms involved and not involved in M\&A ( $\mathrm{hu} \mathrm{\&} \mathrm{Lu}, 2013$ ). We tried to explore the contributions of behavioral finance to study in depth the reality and perspectives of REM in the context of M\&A in the presence of overconfidence bias.

Methodologically, we made a considerable effort to collect data on US firms that are involved or not in M\&A. It provided new evidence on the link between CEO overconfidence (Hwang et al., 2020) and REM based on real activities (Elrazaz et al., 2021). Our basic objective was to determine the importance of the behavioral approach in the study of REM in the M\&A market. This study had the privilege of examining this relationship on two sub-samples: US companies involved or not in M\&A transactions. Based on a sample comprising 280 US companies in the S\&P 500 index over the 2012-2018 period. To answer our question, we divided our total sample into two sub-samples according to whether the companies are involved in M\&A transactions (test sample) or not (control sample) (Chouaibi et al., 2019).

The results of our research illustrate some interesting conclusions from a financial and statistical point of view. Indeed, the results of the difference between means test prove that there is a significant difference in the contribution of overconfident manager's behavior between the two groups of companies. To obtain more robust results, we used the multiple linear regression model by regressing our variables on the level of REM in the samples of this work. The empirical results are similar to those of the difference between means test.

Indeed, the regression results show that overconfident manager's behavior affects significantly the REM in companies involved in M\&A but non-significantly in those not involved in M\&A. Therefore, our hypothesis is confirmed. The control variables, such as the size and ROA, have a positive and significant impact on the level of REM in merged and acquiring firms, while the leverage variable and Tobin $\mathrm{Q}$ have a negative and significant impact on the level of REM in merged and acquiring firms.

However, like any research work, our study has certain limitations in terms of the difficulty of collecting data for the M\&A variable, which could skew the results. The limitation of our study is the single behavioral bias of the manager; therefore, future 
research works could examine the impact of other behavioral biases (e.g., CEO Narcissism) on REM in the M\&A market. Similarly, our study did not deal with the different types of M\&A, so future studies may investigate the impact of behavioral bias on the level of REM within the context of horizontal and vertical M\&A. All M\&A transactions of our sample are domestic; however, for companies seeking to be more competitive in the global market, international M\&A are increasingly common. Thus, future research will focus on international M\&A.

\section{References}

Ahmed, A. S., \& Duellman, S. (2013) "Managerial overconfidence and accounting conservatism", Journal of Accounting Research, Vol. 51(1): 1-30

Anderson, D. R., Sweeney, D. J., Williams, T. A., Camm, J. D., \& Cochran, J. J. (2016) Statistics for business \& economics, Nelson Education.

Ben-David, I., Graham, J. R., \& Harvey, C. R. (2007) Managerial overconfidence and corporate policies (No. w13711), National Bureau of Economic Research.

Ben-David, I., Graham, J. R., \& Harvey, C. R. (2013) "Managerial miscalibration", The Quarterly Journal of Economics, Vol. 128(4): 1547-1584.

Bhabra, H. S., \& Huang, J. (2013) "An empirical investigation of mergers and acquisitions by Chinese listed companies, 1997-2007", Journal of Multinational Financial Management, Vol. 23 (3): 186-207.

Chao, C. M., \& Ho, C. H. (2019) "The relationship between corporate social responsibility and abnormal return: mergers and acquisitions events", Review of Integrative Business and Economics Research, Vol. 8 (3):1-23.

Chatterjee, A., \& Hambrick, D. C. (2007) "It's all about me: Narcissistic chief executive officers and their effects on company strategy and performance", Administrative science quarterly, Vol. 52(3): 351-386.

Cho, C. H., Michelon, G., Patten, D. M., \& Roberts, R. W. (2015) "CSR disclosure: the more things change...?", Accounting, Auditing \& Accountability Journal, Vol. 28 (1): 14- 35.

Chouaibi, J., Zouari, G., \& Khlifi, S. (2019) "How does the real earnings management affect firms innovative? Evidence from US firms", International Journal of Law and Management, Vol. 61 (1):151-169.

Cioli, V., Giannozzi, A., Ippoliti, V., \& Roggi, O. (2020) "Cross-border M\&A and financial performance: empirical evidence on bidder/target companies", International Journal of Business and Management, Vol. 15 (4): 67-86.

Cohen, D. A., \& Zarowin, P. (2010) "Accrual-based and real earnings management activities around seasoned equity offerings", Journal of Accounting and Economics, Vol. 50 (1):2-19.

Cohen, D. A., Dey, A., \& Lys, T. Z. (2008) "Real and accrual-based earnings management in the pre-and post-Sarbanes-Oxley periods", The Accounting Review, Vol. 83(3): 757-787. 
Custódio, C., \& Metzger, D. (2013) "How do CEOs matter? The effect of industry expertise on acquisition returns", The Review of Financial Studies, Vol. 26 (8): 2008-2047.

Dechow, P. M., Kothari, S. P., \& Watts, R. L. (1998) "The relation between earnings and cash flows", Journal of Accounting and Economics, Vol. 25 (2), 133-168.

Deshmukh, S., Goel, A. M., \& Howe, K. M. (2013) "CEO overconfidence and dividend policy", Journal of Financial Intermediation, Vol. 22 (3):440-463.

Dezi, L., Battisti, E., Ferraris, A., \& Papa, A. (2018) "The link between mergers and acquisitions and innovation", Management Research Review, Vol. 41(6): 716-752.

Elrazaz, T. Z., Elmassri, M., \& Ahmed, Y. (2021) "Real earnings manipulation surrounding mergers and acquisitions: the targets' perspective", International Journal of Accounting and Information Management, Vol. 29 (3): 429-451.

Erickson, M., \& Wang, S. W. (1999) "Earnings management by acquiring firms in stock for stock mergers", Journal of Accounting and Economics, Vol. 27 (2): 149-176.

Farooqi, J., Jory, S. R., \& Ngo, T. N. (2020) "Target firm earnings management, acquisition premium, and shareholder gains", International Journal of Accounting, Vol. 55(02): 2050009.

Ferris, S. P., Jayaraman, N., \& Sabherwal, S. (2013) "CEO overconfidence and international merger and acquisition activity", Journal of Financial and Quantitative Analysis, Vol. 48(1):137-164.

Graham, J. R., Harvey, C. R., and Rajgopal, S. (2005) "The economic implications of corporate financial reporting", Journal of Accounting and Economics, Vol. 40 (1-3): 3-73

Hambrick, D. C., \& Cannella Jr, A. A. (1993) "Relative standing: A framework for understanding departures of acquired executives", Academy of Management Journal, Vol. 36 (4): 733-762.

Heron, R., \& Lie, E. (2002) "Operating performance and the method of payment in takeovers", Journal of Financial and Quantitative Analysis, Vol. 37 (1): 137-155.

Hribar, P., \& Yang, H. (2011) “CEO overconfidence, managerial earnings forecasts, and earnings management", Working Paper, University of Iowa and Cornell University.

Hribar, P., \& Yang, H. (2016) "CEO overconfidence and management forecasting", Contemporary Accounting Research, Vol. 33(1): 204-227.

Hu, N., Liu, L., \& Miller, W. F. (2013) "The path to reporting economic reality-why all CEOs should have accounting degrees", Journal of Management Policy and Practice, Vol. 14(2):11-18.

Huang, J., \& Kisgen, D. J. (2013) "Gender and corporate finance: Are male executives overconfident relative to female executives?", Journal of Financial Economics, Vol. 108(3): 822-839. 
Hwang, H. D., Kim, H. D., \& Kim, T. (2020) "The blind power: Power-led CEO overconfidence and M\&A decision making", The North American Journal of Economics and Finance, Vol. 52: 101141.

Kervin, J. B. (1992) "Methods for business research", New York: HarperCollins.

Kouaib, A., \& Jarboui, A. (2016) "Real earnings management in innovative firms: Does CEO profile make a difference?", Journal of Behavioral and Experimental Finance, Vol. 12: 40-54.

Krug, J. A., \& Hegarty, W. H. (1997) "Post acquisition turnover among US top management teams: An analysis of the effects of foreign vs. domestic acquisitions of US targets", Strategic Management Journal, Vol. 18 (8): 667-675.

Kuo, Y. F., Lin, Y. M., \& Chien, H. F. (2021) "Corporate social responsibility, enterprise risk management, and real earnings management: Evidence from managerial confidence", Finance Research Letters, Vol. 41:101805.

Levi, M., Li, K., \& Zhang, F. (2014) "Director gender and mergers and acquisitions", Journal of Corporate Finance, Vol. 28:185-200.

Libby, R., \& Rennekamp, K. (2012) "Self-serving attribution bias, overconfidence, and the issuance of management forecasts", Journal of Accounting Research, Vol. 50 (1): 197-231.

Liu, X., \& Zou, H. (2008) "The impact of green field FDI and mergers and acquisitions on innovation in Chinese high-tech industries", Journal of World Business, Vol. 43(3): 352-364.

Malmendier U., Tate G. (2008) "Who makes acquisitions? CEO overconfidence and the market's reaction", Journal of Financial Economics, Vol. 89:20-43.

Malmendier, U., \& Tate, G. (2005) "CEO overconfidence and corporate investment", The Journal of Finance, Vol. 60 (6): 2661-2700.

Nguyen Tuan, V. (2015) Business valuation and pricing in merger and acquisition context: case study, Intel-Altera.

Pikulina, E., Renneboog, L., \& Tobler, P. N. (2017) "Overconfidence and investment: An experimental approach", Journal of Corporate Finance, Vol. 43: 175-192.

Roll, R. (1986) "The hubris hypothesis of corporate takeovers", Journal of Business, Vol. 52 (2): 197-216.

Rovenpor, J. L. (1993) "The relationship between four personal characteristics of chief executive officers (CEOs) and company merger and acquisition activity (MAA)", Journal of Business and psychology, Vol. 8(1): 27-55.

Roychowdhury, S. (2006) "Earnings management through real activities manipulation", Journal of Accounting and Economics, Vol. 42 (3): 335-370.

Schrand, C. M., \&Zechman, S. L. (2012) "Executive overconfidence and the slippery slope to financial misreporting", Journal of Accounting and economics, Vol. 53(1-2): 311-329.

Sutrisno, P., \& Karmudiandri, A (2020) "CEO overconfidence, founder \& restatement of financial reporting", International Journal of Business, Economics and Law, Vol. 23(1): 192-198. 
Zang, A. Y. (2012) "Evidence on the trade-off between real activities manipulation and accrual-based earnings management", The Accounting Review, Vol. 87(2): 675-703.

Zhang, J., Ahammad, M. F., Tarba, S., Cooper, C. L., Glaister, K. W., \& Wang, J. (2015) "The effect of leadership style on talent retention during merger and acquisition integration: Evidence from China", The International Journal of Human Resource Management, Vol. 26(7): 1021-1050.

Zhang, J., Kobert, K., Flouri, T., \& Stamatakis, A. (2014) "PEAR: a fast and accurate Illumina Paired-End read merger", Bioinformatics, Vol. 30 (5): 614-620.

Zhu, X., \& Lu, S. (2013) "Earnings management through real activities manipulation before mergers and acquisitions", Journal of Finance and Accountancy, Vol. 13: 1-17. 